\title{
A TOU Pricing Mechanism to Promote Renewable Energy Consumption: The Case of the Western Inner Mongolia Grid in China
}

\author{
Yong-xiu He, Yue-xia Pang, and Jie Guan \\ School of Economics and Management, North China Electric Power University, Bei Nong Road No. 2, \\ Changping District, Beijing, China \\ Correspondence should be addressed to Yue-xia Pang; pangyuexia@sina.com
}

Received 3 June 2017; Revised 28 July 2017; Accepted 10 August 2017; Published 14 September 2017

Academic Editor: Stefan Balint

Copyright (C) 2017 Yong-xiu He et al. This is an open access article distributed under the Creative Commons Attribution License, which permits unrestricted use, distribution, and reproduction in any medium, provided the original work is properly cited.

\begin{abstract}
The curtailment of wind power and photovoltaic power is becoming increasingly serious from the year 2012 to present in China. And the small installed capacity captive coal-fired power plants have been developed rapidly aiming to cut production costs. Therefore, by the substitution of renewable energy for captive coal-fired power plants, this paper establishes a time-of-use (TOU) pricing mechanism with a linkage between the supply side and the demand side to promote renewable energy consumption, which is applied to the Western Inner Mongolia grid in China. The results show that the benefits to the grid company, electricity users, renewable energy producers, and social environment are influenced by the quantity of renewable energy purchased in the market, the market price for renewable energy, the quantity of electricity from grid to peak shaving, the carbon price, and the quantity of electricity generated by captive coal-fired power plants shifting to grid, in which the first factor has the greatest influence on the benefits of stakeholders. Furthermore, improving the accuracy of renewable energy generation forecast and optimizing using electricity behaviors by considering the renewable energy generation characteristics could ensure the TOU mechanism implementation successfully.
\end{abstract}

\section{Introduction}

Recently, China's renewable energy installed capacity has undergone rapid development. In 2016, China had the largest increment, accumulation in wind power capacity, and photovoltaic power capacity in the world $[1,2]$. However, renewable energy development has led to a serious curtailment problem; the curtailment rate for wind power in Inner Mongolia was $21 \%$ in 2016 [3]. This brought about huge economic and environmental losses to China. Moreover, in the Paris Climate Conference of 2015, China proposed to decrease its carbon dioxide $\left(\mathrm{CO}_{2}\right)$ emissions per unit of GDP by $60 \% \sim 65 \%$ in 2030 compared with 2005 [4] and to increase its nonfossil energy use to about $20 \%$ of its primary energy consumption [5]. Under these proposals, alleviating the curtailment of wind power and photovoltaic power has become an unavoidable problem. Promoting renewable energy consumption can not only reduce economic losses, but also promote the achievement of emission reduction targets and improve environmental quality.

At present, domestic and foreign scholars have studied the policy mechanisms and technology that promote renewable energy consumption. The impact of renewable energy on economic growth in the Black Sea and Balkan countries has been explored, and bidirectional causality between renewable energy consumption and economic growth has been found [6]. The problems of renewable energy price policies have been analyzed $[7,8]$. For example, in China, a good match between the various types of renewable energy policies is a better way of promoting renewable energy consumption [9]. In Germany, public acceptance, preferences, and the political economy related to renewable energy have been studied, with the aim of promoting renewable energy development $[10,11]$. In order to promote renewable energy consumption, four types of feed-in tariff mechanisms and profit distribution patterns have been analyzed in China [12]. A threshold test 
TABLE 1: The average curtailment rate of wind power in China from 2012 to 2015.

\begin{tabular}{lcccc}
\hline Year & 2012 & 2013 & 2014 & 2015 \\
\hline The average curtailment rate of wind power & $17.12 \%$ & $10.74 \%$ & $8 \%$ & \\
\hline
\end{tabular}

has been employed to analyze the impact of subsidies on overcapacity [13]. The dynamic and complex relationship between renewable energy investors, consumers, and policymakers has been analyzed to optimize the subsidy policy [14]. If the investment in installed capacity is to take market supply and demand into account, the power generation subsidy should correspond to the externalities of renewable energy (such as greenhouse gas reduction) [15].

There are, at present, many works that focus on TOU price mechanisms. Some scholars proposed that peak load pricing can plausibly reduce prices by making price competition more severe and thereby reducing profits [16]. A novel control methodology has been presented as an off-peak ground precooling strategy [17]. A power structure using economic models of price responsive loads has been constructed that takes into account price elasticity of electricity demand, perceived price, and the interests of customers to estimate the influence of a regional electricity price policy and TOU policy [18].

In addition, TOU block pricing is a combination of TOU pricing and block pricing. The residential electricity demand under TOU pricing with increasing block pricing (IBP) has been analyzed. The result shows that IBP could increase price elasticity significantly [19]. Electricity demand behaviors under a TOU block tariff and a pure TOU tariff have been analyzed, based on a two-level demand model with residential electricity and micro family data such as home appliances [20].

The effect of a TOU price mechanism has been evaluated. In a perfectly competitive market, marginal cost pricing is the best method of maximizing social welfare [21]. Scholars have proposed an optimal TOU pricing mechanism in the urban gas market on the basis of an evolutionary gametheoretic perspective [22]. A static deterministic linear peak load pricing model that finds the optimal mix of generation technologies for a given duration curve has been established [23]. A pilot study was used to assess the impact of real-time price visualization of residential electricity consumption, and the impact on costs and carbon (equivalent carbon dioxide $\left(\mathrm{CO}_{2} \mathrm{eq}\right)$ ) emissions was calculated, using hourly dynamic $\mathrm{CO}_{2}$ eq intensity [24].

In summary, there are many literatures about renewable energy development and TOU pricing mechanisms. However, there was limited work that takes into account the carbon emissions trading market, the interaction between supply and demand, and the use of a TOU pricing mechanism to promote renewable energy consumption. This paper combines renewable energy with a TOU pricing mechanism through the substitution of renewable energy for captive coal-fired power plants, considering the benefits for the grid company, electricity users, renewable power generators, and social environment, to establish a TOU pricing mechanism to promote renewable energy consumption.
Section 2 analyzes the current status of renewable energy development and TOU price implementation in China. Section 3 constructs the TOU pricing model and the benefits analysis model. Section 4 takes the Western Inner Mongolia grid as an example to evaluate the benefits for stakeholders under the TOU pricing model of Section 3. The discussion about TOU pricing model from the perspective of stakeholders is presented in Section 5. Section 6 puts forward conclusions and makes recommendations.

\section{The Current Situation of Renewable Energy Development and TOU Price Implementation in China}

2.1. An Analysis of the Renewable Energy in China. In 2016, the thermal power generation capacity accounted for $64 \%$ of the total power generation capacity, while wind power and photovoltaic power accounted for $9 \%$ and $5 \%$, respectively [25]. However, the utilization efficiency of renewable energy is not high. The average wind power curtailment rate for the whole country fluctuated at around 10\% from 2012 to 2015, as shown in Table 1 [26-28]. According to data from the National Energy Administration in China, in 2016 the wind power curtailment is $49.7 \mathrm{TWh}$, which brought about serious economic losses to China.

According to the "Renewable Energy Development Plan," China's renewable energy consumption will amount to $15 \%$ of primary energy consumption by 2020 . Therefore, to achieve this goal and solve renewable curtailment problem, China still needs to adjust its energy consumption structure and gradually expand its renewable energy consumption.

\subsection{The Current State of TOU Pricing Mechanism in China.} A TOU price is an economic means of encouraging users to change their electricity consumption behaviors by avoiding peak electricity. The TOU price started from the year of 1985 in China; then, the TOU price could fluctuate based on the grid average price in 1987, according to "Notice on the Implementation Method of a Variety of Electricity Price." In 2003 , in order to ease the power shortage in some areas, the scope of implementation of TOU was expanded based on the overall level of power unchanged. Up to July 2017, 27 provinces in China had implemented a TOU pricing scheme, and four provinces had not (Sichuan, Guizhou, Tibet, and part of Inner Mongolia). The TOU price, which is formulated by floating ratio method, has achieved the electricity peak shaving and eased the power shortage situation in peak period. And there are some lessons that should be given attention.

(1) In order to remain the stable power price, in general, shoulder price jumps up and down lightly based on benchmark price which is formulated according to 
the electricity price approved by National Development and Reform Commission of China (NDRC).

(2) In order to achieve peak shaving, the coverage of TOU price mechanism should fully take the various users' power consumption proportion of total power consumption in this area, the difference of peak load and off-peak load, and users' potential of peak shaving into consideration.

Although many provinces in China have implemented TOU pricing, there is still a serious problem with renewable energy curtailment. The reasons are as follows.

Firstly, in recent years, many industrial users are utilizing and establishing captive power plants to generate electricity as soon as possible with the aim of cutting their production costs. However, in general, the captive power plants are coalfired units with higher pollution, and the marginal cost of captive coal-fired power plants is lower than the off-peak price of TOU. Therefore, the full use of those plants could reduce the load demand in demand side and influence the generated output of renewable energy.

Secondly, at present, TOU pricing focuses on adjusting the difference between the peak load and the off-peak load for the whole grid and easing the shortage of power, not considering the renewable energy consumption [29-32]. For example, the TOU pricing has been carried out in Gansu of China from the year of 1995, aiming to encourage the behaviors of peak shaving, but the curtailment of renewable energy is serious. And in 2016, the curtailment rate of wind power was $43.11 \%$ [33].

Thirdly, with the rapid development of renewable energy, there is presently an oversupply in the power market. And it is still difficult with existing technology to store large quantity of power.

2.3. Analysis regarding the Demand for Large-Scale Renewable Energy on Grid with TOU Pricing. The random and fluctuating nature of the large-scale renewable energy on-grid supply means that ancillary service is needed to maintain grid operation stable. However, there is no market mechanism for the ancillary service market in China; a largescale renewable energy on-grid supply becomes difficult. Therefore, demand side management, especially the price mechanism, has become an effective means of promoting renewable energy consumption, given the current market conditions and technology levels. At present, the renewable energy installed capacity in China is concentrated on the Northwestern regions, such as Gansu, Xinjiang, and Inner Mongolia. In Western Inner Mongolia, from Figures 1 and 2 [34], it can be seen that the peak period of wind power output is the off-peak load period generally. In Ningxia and Gansu, the photovoltaic power output exists in the off-peak load period from Figure 3 [35] and Figure 4. Therefore, in the Northwestern region of China, the renewable energy could take place in off-peak time.

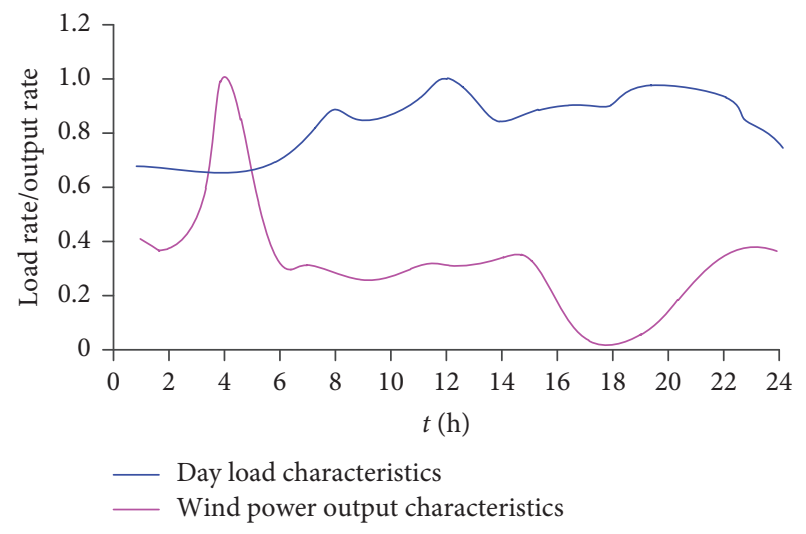

FIGURE 1: Comparative analysis of wind generation and day load in typical summer day of Western Inner Mongolia.

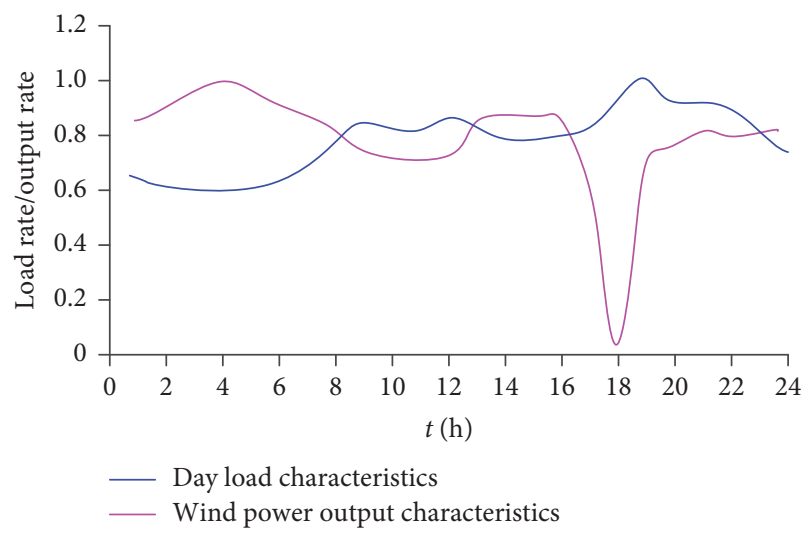

FIGURE 2: Comparative analysis of wind generation and day load in typical winter day of Western Inner Mongolia.

Considering that the renewable energy generation in China usually takes place during off-peak times, three requirements need to be met if the TOU pricing mechanism is to promote large-scale renewable energy consumption:

(1) Using of the advantage that the marginal cost of renewable energy is almost zero to attract users to expand their off-peak electricity consumption

(2) Achieving reasonable connections among the generation, the transmission and the distribution of electric power, and selling power with the aim of transferring the low purchase cost of renewable energy in supply side to the demand side

(3) Highlighting the advantage that renewable energy is clean energy and combining it with the carbon emission trading market.

\section{TOU Pricing Model and Benefit Analysis for Promoting Renewable Energy Consumption}

3.1. TOU Pricing Model for Promoting Renewable Energy Consumption. Recently, in order to have adequate electricity for own use in a low price, power users have set up many 


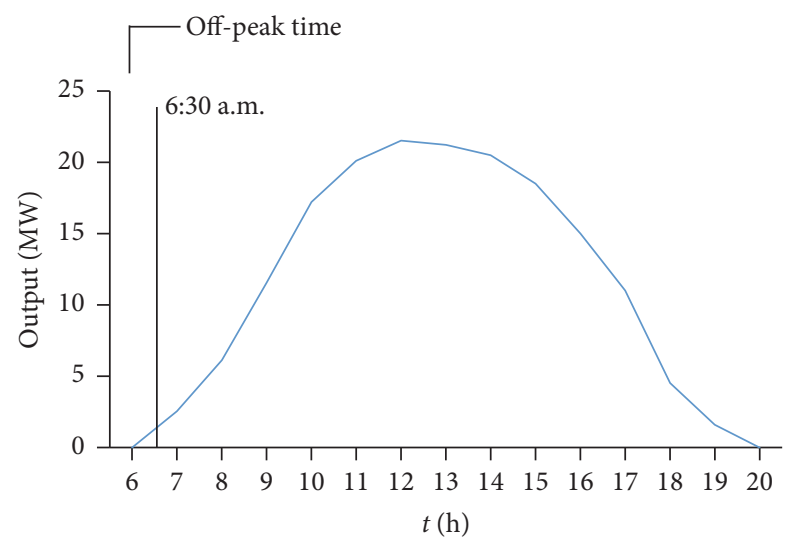

FIgURE 3: Typical $30 \mathrm{MW}$ photovoltaic power plants day output in Ningxia.

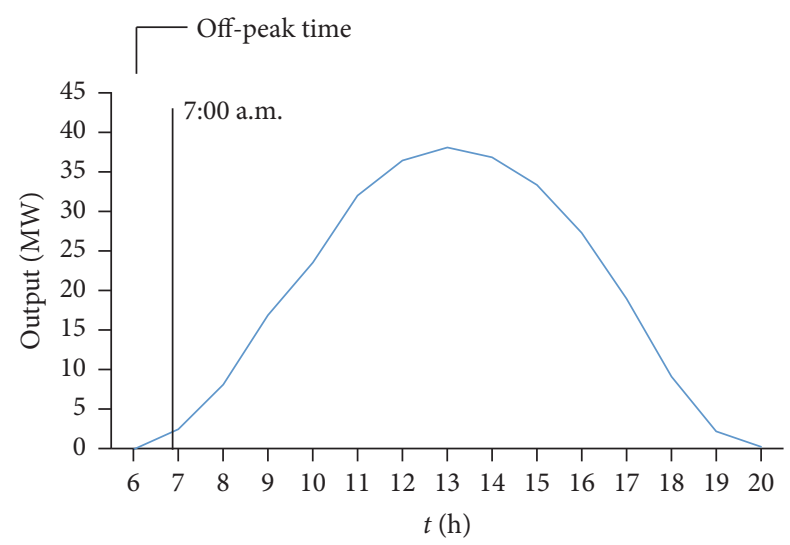

Figure 4: Typical $50 \mathrm{MW}$ photovoltaic power plants day output in Gansu.

captive coal-fired power plants. Meanwhile, the renewable energy increases rapidly with the policy support from the government in order to enhance the environment protection. The situation of energy development makes the renewable energy curtailment more and more severe, especially when the power is oversupply, such as Gansu, Xinjiang, and Inner Mongolia of China. Therefore, a TOU pricing mechanism using a not higher power price than the marginal cost of power from captive coal-power plant in off-peak period is an effective way to encourage substitution of renewable energy for captive coal-fired power plants. For example, in adequate supply areas of renewable energy and captive coal-fired power plants, the TOU pricing mechanism encourages renewable energy consumption. In short supply areas of renewable energy, the TOU pricing mechanism could expand users' electricity demand for renewable energy, which is beneficial to attract renewable energy investment.

According to "measures for the administration of the full acquisition of renewable energy generation" issued by NDRC in 2016, if more electricity is produced by renewable energy enterprises than that has been arranged, this can be traded by the bidding method. Thus, in an overcapacity situation, renewable energy enterprises can utilize their low marginal costs advantage to compete with other producers to improve their profits and decrease the wind power and photovoltaic power curtailment rate.

Compared with the existing TOU pricing mechanism in China, the aims of TOU pricing mechanism proposed in this paper are to not only shift the peak load, but also replace captive coal-fired power plants by off-peak pricing to improve the renewable energy consumption. The main idea of the model is to make the off-peak price not higher than marginal cost of power from captive coal-fired power plants on the demand side and to purchase low price renewable energy through a marketing approach on the supply side. Ultimately, a price for peak load will be calculated based on the price for shoulder load and the revenue of the grid company which is held constant. In this model, considering the predictability of electricity demand and the immatureness of carbon trading market in some areas, the quantity electricity and carbon price are set as exogenous variable, and the power price is endogenous variable. And combined with the TOU price development at home and abroad, it is indigenous in China that the shoulder price is equal to current electricity price. The peak price is calculated according to the off-peak price, shoulder price, and electricity quantity of peak, shoulder, and off-peak that is universally accepted and used by many scholars to calculate TOU price $[36,37]$. In case of the substitution of renewable energy for captive coal-fired plants, making the off-peak price not higher than captive coal-fired plants is ad hoc assumptions, which is an innovation in this paper.

The off-peak price is calculated according to the marginal cost of captive coal-fired power plants. According to Chinese laws and regulations, the marginal cost of captive coal-fired power plants consists of the marginal production cost, the reserve capacity expenses of the power system, government funds, and structural adjustment funds. In addition, with the development of China's carbon emissions trading market, the value of carbon emissions needs to be considered in the marginal cost of captive coal-fired power plants. In order to ensure that the use of the power grid is the better alternative, the off-peak power price should be not higher than the marginal cost of the captive coal-fired power plants. The calculation method is shown in

$$
P_{\text {off-peak }} \leq C_{p}+T_{1}+T_{2}+T_{3}+P_{r} \times E_{\mathrm{CO}_{2}}
$$

where $P_{\text {off-peak }}$ represents the off-peak power price, $C_{p}$ represents the production cost for captive coal-fired power plants, $T_{1}$ is reserve capacity expenses of the power system, $T_{2}$ is government funds, including rural grid loan repayment funds, the national large-scale water projects construction fund, the large- and medium-sized reservoir resettlement support fund, renewable energy price surcharges, and city public utilities surcharges, $T_{3}$ is structural adjustment funds, $P_{r}$ is carbon price, and $E_{\mathrm{CO}_{2}}$ is $\mathrm{CO}_{2}$ emissions per $\mathrm{kWh}$ of the captive coal-fired power plants.

$E_{\mathrm{CO}_{2}}$ is calculated from the per $\mathrm{kWh}$ standard coal consumption of captive coal-fired power plants and the $\mathrm{CO}_{2}$ 
emissions for standard coal. The specific calculation method is shown as

$$
E_{\mathrm{CO}_{2}}=Q_{\text {coal }} \times \kappa,
$$

where $Q_{\text {coal }}$ represents the per kWh standard coal consumption of captive coal-fired power plants and $\kappa$ represents the $\mathrm{CO}_{2}$ emissions for standard coal.

In order to ensure the power price stable and draw lesson from Chinese TOU mechanism, the shoulder price is equal to the current electricity price considering the user's electricity expenditure level and psychological acceptance. The calculation formula is shown as

$$
P_{\text {shoulder }}=P_{0} \text {, }
$$

where $P_{\text {shoulder }}$ is the shoulder price and $P_{0}$ is the current electricity price.

The main idea of using the TOU pricing model to promote renewable energy consumption is that the benefits of the grid company must be the same as they are in the current situation. However, considering the volatility of renewable energy supply, the quantity of renewable energy consumption may be limited, which needs to be decided by related grid technology and ancillary service market development. The specific calculation method is shown in

$$
\begin{aligned}
& G_{\text {profit }}=\left(P_{0}-c\right) \times\left(Q_{\text {peak }}+Q_{\text {shoulder }}+Q_{\text {off-peak }}\right) \\
& G_{\text {profit }}^{\prime} \\
& =Q_{\text {peak }} P_{\text {peak }}+Q_{\text {shoulder }} P_{\text {shoulder }} \\
& +P_{\text {off-peak }}\left(Q_{\text {off-peak }}+Q_{\text {replace-off-peak }}\right) \\
& -\left(c_{\text {thermal }}^{\prime} Q_{\text {thermal }}+c_{\text {renewable }}^{\prime} Q_{\text {renewable }}\right)-\Delta I \\
& \times \lambda_{n}-\Delta C_{o} \\
& G_{\text {profit }}^{\prime}=G_{\text {profit }} \\
& Q_{\text {thermal }}+Q_{\text {renewable }} \\
& =Q_{\text {peak }}+Q_{\text {shoulder }}+Q_{\text {off-peak }}+Q_{\text {replace-off-peak }} \text {, }
\end{aligned}
$$

where $G_{\text {profit }}$ represents grid company's current gross profit, $G_{\text {profit }}^{\prime}$ represents grid company's gross profit when the TOU price is carried out. $P_{\text {peak }}, P_{\text {shoulder }}, P_{\text {off-peak }}$ represent peak price, shoulder price, and off-peak price, and $Q_{\text {peak }}, Q_{\text {shoulder }}$, $Q_{\text {off-peak }}, Q_{\text {replace-off-peak }}$ represent the peak electricity, shoulder electricity, off-peak electricity without considering the quantity of electricity from the power grid that replaces electricity from captive power plants during the off-peak period, and the quantity of electricity from the power grid that replaces electricity from captive power plants during the off-peak period, $c$ is the current average power costs, $c_{\text {thermal }}^{\prime}, c_{\text {renewable }}^{\prime}$ are the purchase costs of thermal power and renewable energy power when the TOU pricing model is in place, $Q_{\text {thermal }}, Q_{\text {renewable }}$ are the thermal power and renewable energy power when the TOU pricing model is in place, $P_{0}$ is current sale price of power, $\Delta I$ is the investment required for changes in smart meter purchase and installation when the TOU pricing model is in place, $\lambda_{n}$ is the coefficient of investment recovery in the $n$th year, $n$ is the payback period for the investment in the smart meter purchase and installation, and $\Delta C_{o}$ is the annual operation and maintenance cost changes for having a smart meter.

$Q_{\text {replace-off-peak }}$ is related to the total power generated by captive coal-fired power plants and to the users' response to electricity from the power grid replacing electricity from captive coal-fired power plants during off-peak period, which is called shift to grid in this paper. The calculation method is shown in

$$
Q_{\text {replace-off-peak }}=Q_{\text {captive }} \times \omega \text {, }
$$

where $Q_{\text {captive }}$ represents total power generated by captive coal-fired power plants and $\omega$ is the shift to grid.

In the term for the coefficient of investment recovery, the equal value net recovery calculation method is used. The coefficient of investment recovery is calculated using

$$
\lambda_{n}=\frac{i(1+i)^{n}}{(1+i)^{n}-1},
$$

where $i$ is the discount rate.

The changed costs for the annual operation and maintenance of smart meters are related to the purchase costs of smart meters. Because the operation and maintenance costs only need to be paid for smart meters that are installed when TOU pricing mechanism is carried out, the current operation and maintenance cost of a smart meter is zero. The calculation method is shown in

$$
\Delta C_{o}=C_{\text {equipment }} \times \eta,
$$

where $C_{\text {equipment }}$ is the purchase costs of smart meters and $\eta$ is the operating and maintenance cost rate.

According to the above research, the power peak price is calculated by

$$
\begin{aligned}
P_{\text {peak }}= & \frac{\left(c_{\text {thermal }}^{\prime} Q_{\text {thermal }}+c_{\text {renewable }}^{\prime} Q_{\text {renewable }}\right)+\left(P_{0}-c\right) \times\left(Q_{\text {peak }}+Q_{\text {shoulder }}+Q_{\text {off-peak }}\right)+I \times \lambda_{n}}{Q_{\text {peak }}} \\
& +\frac{C_{o}-Q_{\text {shoulder }} P_{\text {shoulder }}-P_{\text {off-peak }}\left(Q_{\text {off-peak }}+Q_{\text {replace-off-peak }}\right)}{Q_{\text {peak }}} .
\end{aligned}
$$




\subsection{Benefits Analysis Model for Stakeholders}

3.2.1. Benefits Analysis Model for the Grid Company. The changes in the benefits for grid company depend on its income changes and its cost changes. The income changes are related to changes in the sale price for power and to changes in the quantity of electricity. The specific calculation method is shown in

$$
\begin{aligned}
\Delta Y_{\text {grid }}= & P_{\text {peak }} Q_{\text {peak }}+P_{\text {shoulder }} Q_{\text {shouleder }} \\
& +P_{\text {off-peak }}\left(Q_{\text {off-peak }}+Q_{\text {replace-off-peak }}\right) \\
& -P_{0}\left(Q_{\text {peak }}+Q_{\text {shouleder }}+Q_{\text {off-peak }}\right)
\end{aligned}
$$

where $\Delta Y_{\text {grid }}$ is the income changes for the grid company after TOU pricing mechanism is introduced.

The changes in the costs for the grid company consist of the changes in the purchase cost for the total electricity, investment changes for the annual smart meters purchases and installation when TOU pricing mechanism is introduced, and the annual operation and maintenance cost changes for the smart meters. The specific annual cost changes are shown in

$$
\begin{aligned}
\Delta C_{\text {grid }}= & \Delta C_{\text {purchase }}+\Delta I \times \lambda_{n}+\Delta C_{o} \\
\Delta C_{\text {purchase }}= & c_{\text {thermal }}^{\prime} Q_{\text {thermal }}+c_{\text {renewable }}^{\prime} Q_{\text {renewable }} \\
& -c\left(Q_{\text {peak }}+Q_{\text {shoulder }}+Q_{\text {off-peak }}\right),
\end{aligned}
$$

where $\Delta C_{\text {grid }}$ represents cost changes for grid company and $\Delta C_{\text {purchase }}$ represents changes in the purchase costs for the total electricity.

Combining formulas (9)-(11), the changes in the benefits for the grid company can be expressed as

$$
\Delta R_{\text {grid }}=\Delta Y_{\text {grid }}-\Delta C_{\text {grid }}
$$

where $\Delta R_{\text {grid }}$ is the changes in the benefits for the grid company after TOU pricing mechanism is introduced.

3.2.2. Benefits Analysis Model for Electricity Users. The changes in the benefits for electricity users consist of changes in their electricity bills and changes in the operating costs of captive coal-fired power plants. The specific calculation is shown in

$$
\begin{aligned}
\Delta R_{\text {user }}= & P_{\text {peak }} Q_{\text {peak }}+P_{\text {shouleder }} Q_{\text {shoulder }} \\
& +P_{\text {off-peak }} Q_{\text {off-peak }} \\
& -P_{0}\left(Q_{\text {peak }}+Q_{\text {shoulder }}+Q_{\text {off-peak }}\right) \\
& -\left(C_{p}+T_{1}+T_{2}+T_{3}+P_{r} \times Q_{u}\right) \\
& \times Q_{\text {replace-off-peak }},
\end{aligned}
$$

where $\Delta R_{\text {user }}$ is the change in the expenditure of the users.
3.2.3. Benefits Analysis Model for Renewable Energy Producers. Given that the marginal cost of renewable energy is close to zero, the changes in benefits are the changes in income. The specific calculation method is shown as

$$
\Delta R_{\mathrm{rp}}=\left(P_{\mathrm{rp}}+P_{r} \times E_{\mathrm{CO}_{2}}\right) \times Q_{\mathrm{rp}},
$$

where $\Delta R_{\mathrm{rp}}$ is change in the benefits for renewable energy producers, $P_{\mathrm{rp}}$ is renewable energy feed-in tariff set by the market, and $Q_{\mathrm{rp}}$ is the renewable energy consumed as a result of market transactions.

3.2.4. Benefits Analysis Model for Social Environment. The social environment benefits are the reduction of $\mathrm{CO}_{2}$ emissions from renewable energy consumption. The calculation method is shown in

$$
\Delta E=Q_{\mathrm{rp}} \times E_{\mathrm{CO}_{2}},
$$

where $\Delta E$ is the reduction of $\mathrm{CO}_{2}$ emissions from renewable energy consumption.

\section{Case Study}

4.1. Basic Data. Western Inner Mongolia belongs to the Northwestern region of China. No TOU pricing mechanism had been introduced by July 2017. The main reasons are that the goal of current TOU pricing mechanism in China is peak shaving, not showing the direct relationship with renewable energy. Also there is not so much difference between peak load and off-peak load in Western Inner Mongolia. However, the TOU pricing mechanism to promote the renewable energy consumption in this paper is suitable for Western Inner Mongolia of China. The reasons are follows. First, the TOU pricing mechanism's targets in this paper are not only peak shaving, but promoting renewable energy consumption by the substitution of renewable energy for captive coalfired power plants. Second, as for the energy development of Western Inner Mongolia, the renewable energy and captive coal-fired power plants obtain rapid development; there is serious curtailment of renewable energy and environmental pollution. In addition, formulating the TOU price and implementing the substitution of wind power for captive power plants are encouraged in Western Inner Mongolia [38].

Recently, captive coal-fired power plants have undergone rapid development in Western Inner Mongolia. By the end of 2015, the installed capacity of captive power plants had reached $9.26 \mathrm{GW}$, and the power generated was $57.39 \mathrm{TWh}$ including 53.49 TWh for captive consumption. The electricity consumed from grid company was only $18.73 \mathrm{TWh}$, which accounted for $35 \%$ of captive consumption. This electricity consumption behavior will have serious effects on the environment.

Industrial users are taken as an example for analyzing the use of the TOU pricing mechanism proposed in this paper. Since the load characteristics of industrial users are relatively stable and the difference between peak load and offpeak load is small, the peak, shoulder, and off-peak electricity figures are set at one-third of the whole industry. The quantity 
of industry electricity demand is obtained according to the "13th Five-Year Plan" load prediction of Western Inner Mongolia grid and the electricity consumption in 2015. As for grid company's purchased costs, thermal power costs are determined by coal price and coal consumption of per kWh. And the purchased electricity is dominated by thermal power in 2015. Therefore, it is assumed that thermal power cost is the same with current average purchase cost, considering the coal richness of Inner Mongolia.

In addition, to investigate shift to grid, three scenarios are designed. The basic data are shown in Table 2 .

By the end of the year 2015, the wind power installed capacity in Western Inner Mongolia was 14,976.94 MW, and the photovoltaic installed capacity was 4,083 MW. According to the relevant laws and regulations of Inner Mongolia, when the renewable energy utilization hours exceed $1,600 \mathrm{~h}$, the renewable energy producers can participate in market transactions. The renewable energy power generation is therefore $30.50 \mathrm{TWh}$, including 23.96 TWh wind power and 6.53 TWh photovoltaic power. According to the "Notice on the Expected Control Goal for Power Generation of the Western Inner Mongolia Power Grid in 2016 ((2016) No. 74)" issued by the Inner Mongolia Autonomous Region Economic and Information Commission, the thermal power generation is $17.183 \mathrm{TWh}$, the wind power generation is $28.15 \mathrm{TWh}$, and the photovoltaic power generation is 6.94 TWh in Western Inner Mongolia in 2016. Under the control goal, the power that can be traded by the market is $4.59 \mathrm{TWh}$, which includes $4.19 \mathrm{TWh}$ wind power and $0.41 \mathrm{TWh}$ photovoltaic power. The data are shown in Table 3.

In addition, combined with the grid technology and the development of ancillary service market, the largest quantity of wind power has exceeded $25 \%$ of the whole electricity from grid [39]. According to load prediction of the "13th Five-Year Plan" of Western Inner Mongolia grid, the total electricity demand is $192.5 \mathrm{TWh}$ in 2016 . The renewable energy is 35.09 TWh from Table 3, which is lower than $25 \%$ of the electricity demand in 2016. So, the renewable energy which can be traded by market in 2016 is 4.59 TWh.

4.2. The Calculation of the TOU Price. The marginal cost of captive coal-fired power plants in Western Inner Mongolia is shown in Table 4.

In order to improve the competitiveness of the electricity from the power grid, the off-peak power price is 0.02 Yuan/kWh below the marginal cost for captive coal-fired power plants. Therefore, according to Table 3 and formula (1), the off-peak power prices are shown in Table 5.

According to formula (2), the specific data are shown in Table 6.

According to the investigation of Western Inner Mongolia, when the off-peak price is 0.02 Yuan/kWh below the marginal cost for captive coal-fired power plants, the electricity shift to grid is not more than $5 \%$. However, because the captive coal-fired power plants' fixed cost will increase per $\mathrm{kWh}$ when the power generation by captive coal-fired power plants reduces, the shift to grid is assumed to be $0,2 \%$, and $4 \%$. So, combined with formula (8), the power price is shown in Table 7 under different shift to grid.
TABle 2: Basic data.

\begin{tabular}{|c|c|c|}
\hline Items & Units & Value \\
\hline Current average purchase cost & Yuan/kWh & 0.2389 \\
\hline Purchase cost of thermal power & Yuan/kWh & 0.2389 \\
\hline The market price for renewable energy & Yuan/kWh & 0.05 \\
\hline $\begin{array}{l}\text { Purchase and installation costs of smart } \\
\text { meters }\end{array}$ & Million Yuan & 0 \\
\hline Operation and maintenance expenses & Million Yuan & 18.834 \\
\hline Operation and maintenance rate & $\%$ & 10 \\
\hline \multicolumn{3}{|l|}{ Industry } \\
\hline \multicolumn{3}{|l|}{$1-10 \mathrm{kV}$} \\
\hline Peak & GWh & 3711.88 \\
\hline Shoulder & GWh & 3711.88 \\
\hline Off-peak & GWh & 3711.88 \\
\hline \multicolumn{3}{|l|}{$35-110 \mathrm{kV}$} \\
\hline Peak & GWh & 2657.58 \\
\hline Shoulder & GWh & 2657.58 \\
\hline Off-peak & GWh & 2657.58 \\
\hline \multicolumn{3}{|l|}{$110-220 \mathrm{kV}$} \\
\hline Peak & GWh & 4277.16 \\
\hline Shoulder & GWh & 4277.16 \\
\hline Off-peak & GWh & 4277.16 \\
\hline \multicolumn{3}{|l|}{$220 \mathrm{kV}$ and above } \\
\hline Peak & GWh & 2483.12 \\
\hline Shoulder & GWh & 2483.12 \\
\hline Off-peak & GWh & 2483.12 \\
\hline
\end{tabular}

Calcium carbide, electric furnace ferroalloy, electrolytic caustic soda, ammonia synthesis, electric furnace calcium magnesium phosphate, electric furnace yellow phosphorus, electrolytic aluminum, polycrystalline silicon, single crystal silicon

$1-10 \mathrm{kV}$

Peak

GWh $\quad 55.19$

Shoulder

Off-peak

GWh $\quad 55.19$

$35-110 \mathrm{kV}$

Peak

Shoulder

55.19

Off-peak

$110-220 \mathrm{kV}$

Peak

Shoulder

Off-peak

GWh $\quad 6305.21$

GWh $\quad 6305.21$

GWh $\quad 6305.21$

GWh $\quad 4781.77$

GWh $\quad 4781.77$

$220 \mathrm{kV}$ and above

Peak

GWh $\quad 4781.77$

Shoulder

GWh $\quad 4986.65$

Off-peak

GWh $\quad 4986.65$

GWh 4986.65

Power generated by captive coal-fired power plants shift to grid

Note: industrial users' smart meters support TOU price implementation, so the purchase and installation costs of smart meters are 0 .

From Table 7, taking 1-10 kV voltage level as an example, it is shown that off-peak price declines from 0.4548 Yuan/kWh to 0.2313 Yuan/kWh in order for captive coal-fired 
TABLE 3: Calculation of the renewable energy that can be traded in the market in Western Inner Mongolia in 2016.

\begin{tabular}{lc}
\hline Items & Value \\
\hline Wind power installed capacity in $2015(\mathrm{MW})$ & 14976.94 \\
Photovoltaic power installed capacity in $2015(\mathrm{MW})$ & 4083 \\
Wind power when utilization hours are $1600 \mathrm{~h}(\mathrm{TWh})$ & 23.96 \\
Photovoltaic power when utilization hours are $1600 \mathrm{~h}(\mathrm{TWh})$ & 6.53 \\
Predicted wind power in $2016(\mathrm{TWh})$ & 28.15 \\
Predicted photovoltaic power in $2016(\mathrm{TWh})$ & 6.94 \\
Wind power which can be traded by market in $2016(\mathrm{TWh})$ & 4.19 \\
Photovoltaic power which can be traded by market in $2016(\mathrm{TWh})$ & 0.41 \\
Renewable energy which can be traded by market in $2016(\mathrm{TWh})$ & 4.59 \\
\hline
\end{tabular}

TABLE 4: The marginal cost of captive coal-fired power plants.

\begin{tabular}{lc}
\hline Items & Value \\
\hline Marginal production cost & 0.15 Yuan $/ \mathrm{kWh}$ \\
Reserve capacity expenses of power system & $35 \mathrm{kV}$ and below: 0.031 Yuan/kWh \\
$110 \mathrm{kV}: 0.027$ Yuan $/ \mathrm{kWh}$ \\
$220 \mathrm{kV}: 0.02 \mathrm{Yuan} / \mathrm{kWh}$ \\
Government funds & 0.02 Yuan/kWh \\
Rural grid loan repayment funds & 0.004 Yuan $/ \mathrm{kWh}$ \\
National large-scale water projects construction funds & 0.0031 Yuan $/ \mathrm{kWh}$ \\
Large and medium-sized reservoir resettlement later support funds & 0.019 Yuan $/ \mathrm{kWh}$ \\
Renewable energy price surcharges & 0.007 Yuan $/ \mathrm{kWh}$ \\
City public utilities surcharges & 0.0054 Yuan $/ \mathrm{kWh}$ \\
Structural adjustment funds & $14.59 \mathrm{Yuan} / \mathrm{t}$ \\
Carbon price & $0.8066 \mathrm{~kg} / \mathrm{kWh}$ \\
$\mathrm{CO}_{2}$ emissions & \\
\hline
\end{tabular}

Note: carbon price data comes from Hubei carbon emission trading center. The reason is that, currently, there are seven pilot areas of carbon emission trading market in China, namely, Beijing, Tianjin, Shanghai, Chongqing, Hubei, Guangdong, and Shenzhen. The industrial structure of Inner Mongolia has a big difference with Beijing, Tianjin, Shanghai, Guangdong, and Shenzhen. And the Chongqing carbon emission trading center is lack of activity.

power plants to be replaced by renewable energy (when the TOU is not carried out, the price is equal to shoulder price in Western Inner Mongolia in this paper). Therefore, the peak price goes from 0.4548 Yuan/kWh to 0.6487 Yuan/kWh to ensure the benefits of grid company. Also, it is shown that the peak power price rises when the shift to grid increases. The main reason for this is that the quantity of electricity in offpeak times increases when shift to grid increases.

\subsection{Benefits Calculation Based on the Benefits Analysis Model}

4.3.1. Benefits Calculation for the Grid Company. Peak shaving is introduced to analyze the benefit changes for the grid company. In this paper, the peak shaving is defined as the rate at which peak power is transferred to off-peak power without considering shift to grid. The specific calculation method is shown in

$$
\theta=\frac{Q_{\text {peak }}-Q_{\text {peak }}^{\prime}}{Q_{\text {peak }}}
$$

where $\theta$ is the peak shaving, $Q_{\text {peak }}$ is the current peak power without shift to grid, and $Q_{\text {peak }}^{\prime}$ is the peak power after the TOU pricing mechanism is introduced, without shift to grid.

For the grid company of Western Inner Mongolia, electricity situations are analyzed with different shift to grid and peak shaving in Figure 5.

Based on Table 7, Figure 5, and formula (9), the income changes for a grid company are shown in Figure 6.

Using formula (10), the cost changes for the Western Inner Mongolia grid company in 2016 when TOU pricing is introduced are shown in Figure 7.

The benefit changes for the grid company in 2016 when a TOU pricing mechanism is introduced are shown in Figure 8.

As we can see from Figure 8, the benefits for the grid company are gradually reduced when the peak shaving and the shift to grid are increased. However, when the peak shaving and the shift to grid are both less than $4 \%$, the benefits for the grid company will increase after a TOU pricing mechanism is introduced. There are two main reasons for this result; first, the increase in shift to grid, which leads to electricity sales increasing, enhances the revenue of the grid 
TABLE 5: Off-peak power prices for different voltage classes.

\begin{tabular}{lccccc}
\hline Items & Units & $1-10 \mathrm{kV}$ & $35-110 \mathrm{kV}$ & $110-220 \mathrm{kV}$ & $220 \mathrm{kV}$ and above \\
\hline Off-peak power price & Yuan $/ \mathrm{kWh}$ & 0.2313 & 0.2313 & 0.2273 & 0.2203 \\
\hline
\end{tabular}

TABLE 6: Shoulder power prices for different voltage classes for industrial users. Unit: Yuan/kWh.

\begin{tabular}{|c|c|c|c|c|}
\hline Items & $1-10 \mathrm{kV}$ & $35-110 \mathrm{kV}$ & $110-220 \mathrm{kV}$ & $220 \mathrm{kV}$ and above \\
\hline Industry & 0.4548 & 0.4398 & 0.4278 & 0.4208 \\
\hline $\begin{array}{l}\text { Calcium carbide, electric furnace ferroalloy, electrolytic caustic soda, } \\
\text { ammonia synthesis, electric furnace calcium magnesium phosphate, } \\
\text { electric furnace yellow phosphorus, electrolytic aluminum, } \\
\text { polycrystalline silicon, single crystal silicon }\end{array}$ & 0.4118 & 0.3968 & 0.3848 & 0.3778 \\
\hline
\end{tabular}

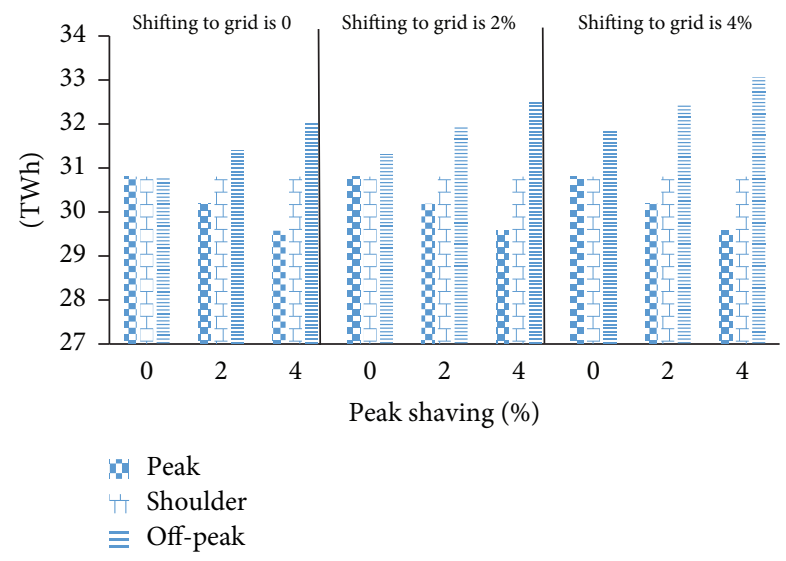

FIGURE 5: Electricity under different peak shaving and shift to grid.

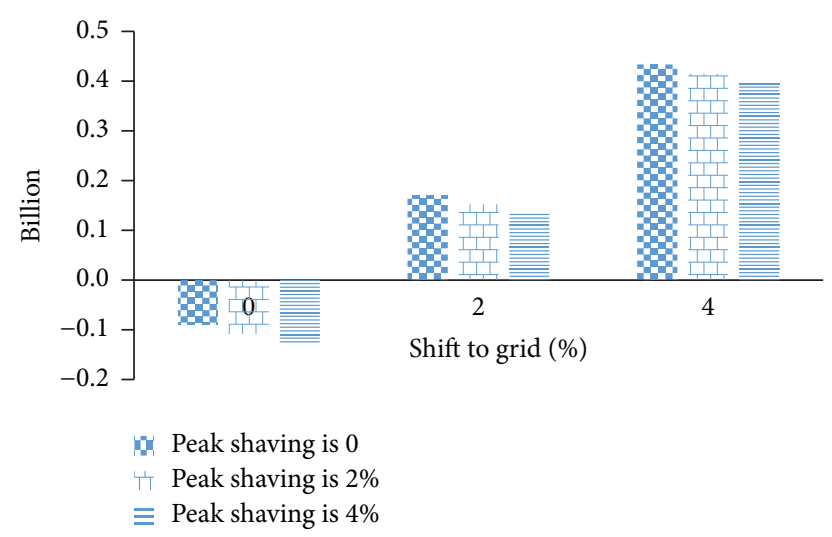

FIGURE 6: Income changes for the grid company in 2016 when a TOU pricing mechanism is introduced.

company. Second, when the peak shaving and the shift to grid are both less than $4 \%$, the savings in the purchase costs for power caused by the presence of low-cost renewable energy in the market are more than the increases in the costs of power caused by the shift to grid. In addition, the implementation of TOU pricing mechanism to promote renewable energy consumption is conducive to peak shaving, which could reduce the grid investment demand of grid enterprises in order to meet the peak load.

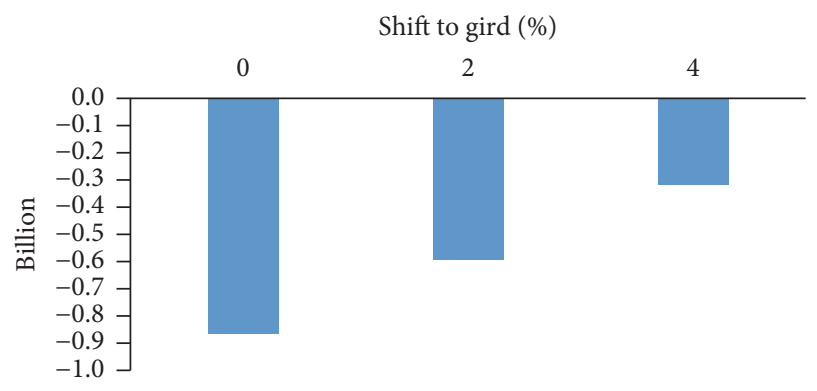

FIGURE 7: Cost changes for the grid company in 2016 when a TOU pricing mechanism is introduced.

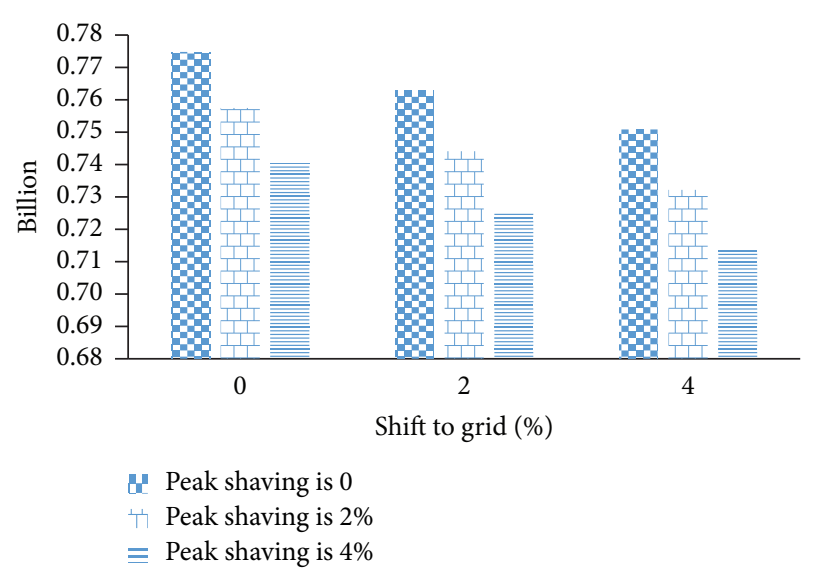

FIGURE 8: Benefit changes for the grid company in 2016 when a TOU pricing mechanism is introduced.

4.3.2. Benefits Calculation for Electricity Users. The changes in the benefits for electricity users are changes in expenses, which consist of changes in the power costs and savings on expenses caused by the consumption of electricity from the grid in place of electricity from captive coal-fired power plants. The benefits changes are shown in Figure 9.

According to Figure 9, electricity users' expenses decrease as the peak shaving and the shift to grid increase. At the same time, when the peak shaving and the shift to grid are positive, the electricity users' expenses will be reduced. The main reason is that the off-peak price is lower than the captive coal-fired power plants' marginal cost. 


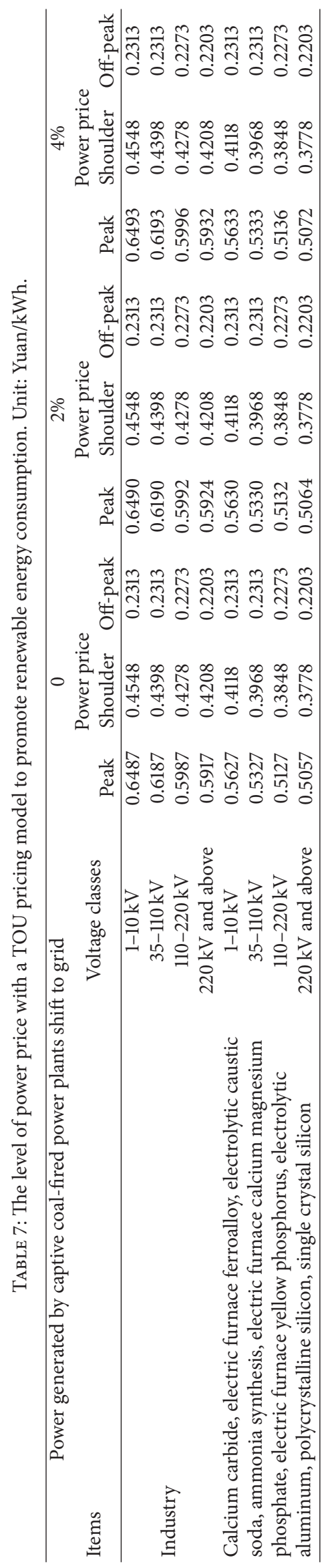


TABLE 8: Changes in the benefits to the social environment.

\begin{tabular}{lccc}
\hline Items & Increased renewable energy & $\mathrm{CO}_{2}$ emissions reduction & Total benefit changes \\
\hline Units & TWh & $\mathrm{kg} / \mathrm{kWh}$ & Thousand tons \\
Value & 4.59 & 0.8066 & 3705.6 \\
\hline
\end{tabular}

TABLE 9: Five factors used in the sensitivity analysis for changes in the benefits for the grid company.

\begin{tabular}{|c|c|c|c|c|}
\hline Items & Units & $-10 \%$ & Baseline scenario & $10 \%$ \\
\hline Peak shaving & - & $1.8 \%$ & $2 \%$ & $2.2 \%$ \\
\hline Power gird enterprise's benefit changes & Billion Yuan & 0.746 & 0.744 & 0.742 \\
\hline Shift to grid & - & $1.8 \%$ & $2 \%$ & $2.2 \%$ \\
\hline Power gird enterprise's benefit changes & Billion Yuan & 0.745 & 0.744 & 0.743 \\
\hline The quantity of renewable energy purchased in the market & TWh & 4.13 & 4.59 & 5.05 \\
\hline Power gird enterprise's benefit changes & Billion Yuan & 0.666 & 0.744 & 0.822 \\
\hline The market price of renewable energy & Yuan/kWh & 0.045 & 0.05 & 0.055 \\
\hline Power gird enterprise's benefit changes & Billion Yuan & 0.765 & 0.744 & 0.724 \\
\hline Carbon price & Yuan/t & 13.131 & 14.59 & 16.049 \\
\hline Power gird enterprise's benefit changes & Billion Yuan & 0.743 & 0.744 & 0.745 \\
\hline
\end{tabular}

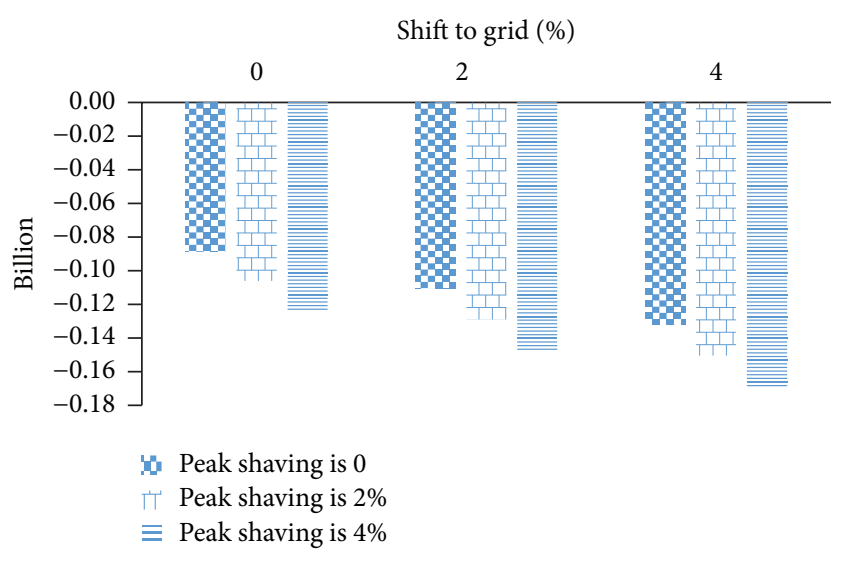

Figure 9: Changes in benefits for electricity users.

4.3.3. Benefits Calculation for Renewable Energy Producers. From Table 3, a total of $4.59 \mathrm{TWh}$ of renewable energy is purchased at low cost in market transactions. Moreover, the marginal cost of renewable energy is close to zero, so the changes in the benefits of renewable energy producers are their income changes. The benefit changes of renewable energy producers are 283.77 million Yuan in 2016.

4.3.4. Benefits Calculation for the Social Environment. The changes in the benefits for the social environment mainly come from the reduction in $\mathrm{CO}_{2}$ emissions. As shown in Table 8, the changes in the benefits to the social environment are 3,705.6 thousand tons.

4.4. Sensitivity Analysis. In this section the effects of main factors on the changes to the benefits of the stakeholders will be analyzed in the scenario in which the peak shaving and the shift to grid are both $2 \%$.
The effects of peak shaving, shift to grid, quantity of renewable energy purchased in the market, market price of renewable energy, and carbon price on the calculations for the grid company are analyzed, and the specific calculation results are shown in Table 9 and Figure 10.

From Figure 10, it can be seen that the quantity of renewable energy purchased on the market has the most influence on the benefits received by the grid company; when the quantity of renewable energy purchased on the market changes by $10 \%$, the benefits to the grid company change by $10.46 \%$. There is a positive relationship between these two variables. Moreover, the benefit to the grid company has a positive relationship with the carbon price. In addition, with the increases in peak shaving, shift to grid, and the market price for renewable energy, the benefits to the grid company will reduce. At the same time, the degree of influence on the benefits to the grid company of the five factors is greatest for the quantity of renewable energy purchased in the market, decreases for the market price for renewable energy, for peak shaving, and for carbon price, and is least for shift to grid.

Overall, the benefits of grid company are determined by income and cost. As shown in Figure 10, the quantity of renewable energy purchased in the market, which has a relationship with cost, has the greatest influence on the benefits to the grid company. Therefore, the grid company should pay more attention to renewable energy generation characteristics and increase the quantity of renewable energy with cheap price actively based on strong and stable big power grid.

The main influencing factors on the benefits for electricity users are peak shaving, shift to grid, quantity of renewable energy purchased in the market, and the market price for renewable energy. The results of the sensitivity analysis are shown in Table 10 and Figure 11.

From Figure 11, it can be seen that the quantity of renewable energy purchased in the market has the most 
TABLE 10: Four factors used in the sensitivity analysis for changes in the benefits to electricity users.

\begin{tabular}{|c|c|c|c|c|}
\hline Items & Units & $-10 \%$ & Baseline scenario & $10 \%$ \\
\hline Peaking shaving & - & $1.8 \%$ & $2 \%$ & $2.2 \%$ \\
\hline Electricity users' expenses & Billion Yuan & -0.129 & -0.131 & -0.133 \\
\hline Shift to grid & - & $1.8 \%$ & $2 \%$ & $2.2 \%$ \\
\hline Electricity users' expenses & Billion Yuan & -0.129 & -0.131 & -0.134 \\
\hline The quantity of renewable energy purchased in the market & TWh & 4.13 & 4.59 & 5.05 \\
\hline Electricity users' expenses & Billion Yuan & -0.122 & -0.131 & -0.140 \\
\hline The market price of renewable energy & Yuan/kWh & 0.045 & 0.05 & 0.055 \\
\hline Electricity users' expenses & Billion Yuan & -0.134 & -0.131 & -0.129 \\
\hline
\end{tabular}

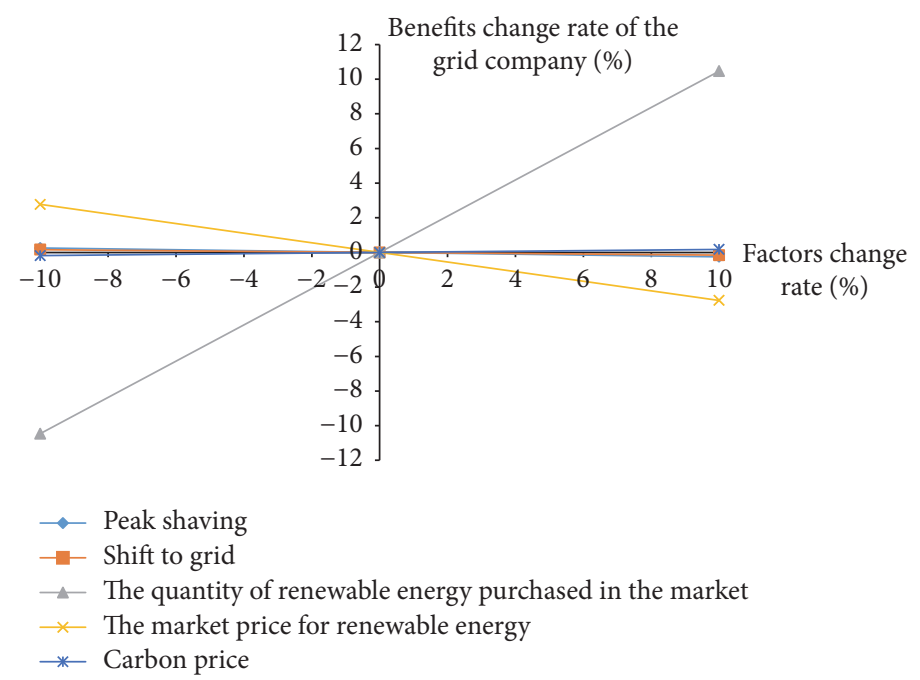

FIGURE 10: Picture of the effects of the five factors used in the sensitivity analysis for changes in the benefits for the grid company.

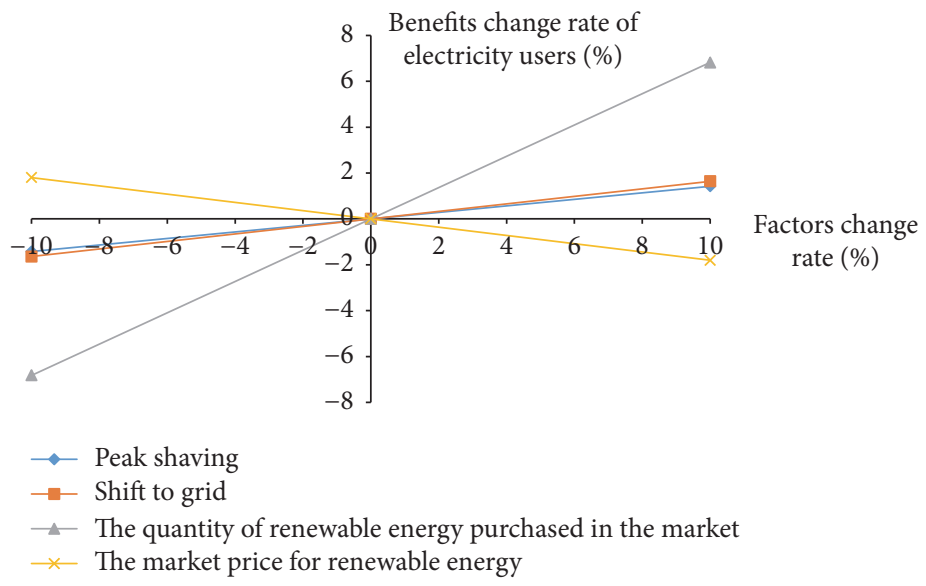

FIgURE 11: Picture of the effects of the four factors used in the sensitivity analysis for changes in the benefits to electricity users.

influence on the changes in electricity users' expenses; when the quantity of renewable energy purchased in the market changes by $10 \%$, the electricity users' expenses change by $6.82 \%$. And if there is an increase in the market price for renewable energy, the expenses of electricity users will increase.
In other words, the degree of influence on the benefits to electricity users of the four factors is greatest for the quantity of renewable energy purchased on the market transaction, then decreases for the market price, for renewable energy, and again for shift to grid, and is least for peak shaving. Since the grid company plays a role of transmitter between 


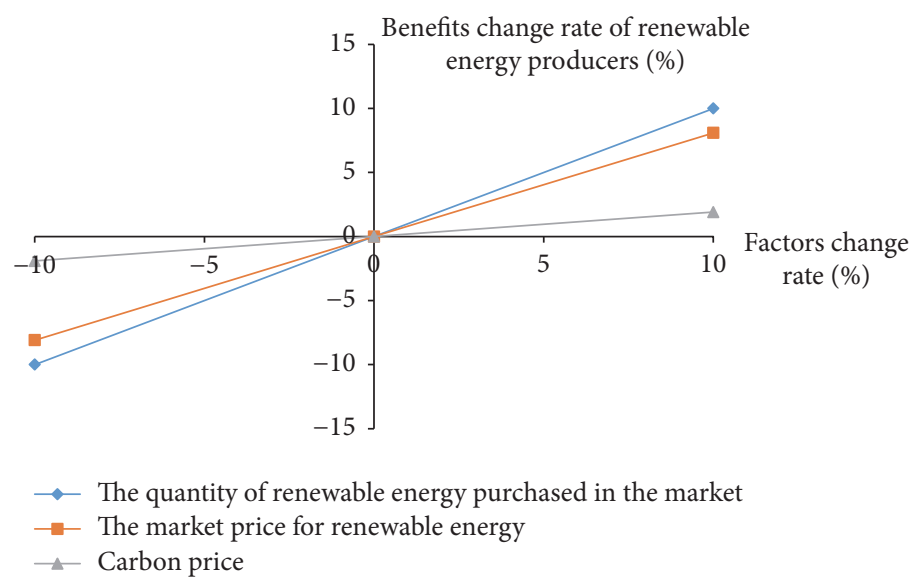

FIGURE 12: Picture of the three factors used in the sensitivity analysis for changes in the benefits to renewable energy producers.

TABLE 11: Three factors used in the sensitivity analysis for the changes in the benefits for renewable energy producers.

\begin{tabular}{lcccc}
\hline Items & Units & $-10 \%$ & Baseline scenario & $10 \%$ \\
\hline The quantity of renewable energy purchased in the market & TWh & 4.13 & 4.59 & 5.05 \\
Renewable energy producers' benefit changes & Million Yuan & 255 & 284 & 312 \\
The market price of renewable energy & Yuan/kWh & 0.045 & 0.05 & 0.055 \\
Renewable energy producers' benefit changes & Million Yuan & 266 & 13.131 & 14.59 \\
Carbon price & Yuan/t & 278 & 284 & 16.049 \\
Renewable energy producers' benefit changes & Million Yuan & & 289 \\
\hline
\end{tabular}

TABLE 12: Sensitivity analysis for the effect of the quantity of renewable energy purchased in the market on the changes in the benefits to the social environment.

\begin{tabular}{lccc}
\hline Items & Units & $-10 \%$ & Baseline scenario \\
\hline The quantity of renewable energy purchased in the market & TWh & 4.13 & $10 \%$ \\
$\mathrm{CO}_{2}$ emissions reduction & Billion Yuan & 33.350 & 5.59 \\
Social environment benefit changes & - & $-10 \%$ & 37.056 \\
\hline
\end{tabular}

supply and demand, the power purchase cost savings by purchasing cheap renewable energy could transmit to users. Then, with the increase of cheap renewable energy, the power expenses will reduce. Therefore, users can optimize using electricity behaviors to reduce power expenses considering the characteristics of renewable energy power generation.

The main factors influencing the changes in the benefits for renewable energy producers are the quantity of renewable energy purchased in the market, the market price for renewable energy, and the carbon price. The sensitivity analysis results are shown in Table 11 and Figure 12.

From Figure 12, it can be seen that the quantity of renewable energy purchased in the market has the most influence on the changes to the benefits to renewable energy producers; when the quantity of renewable energy purchased in the market changes by $10 \%$, the benefits to renewable energy producers change by $10 \%$, and the benefit to renewable energy producers also has a positive relationship with the market price for renewable energy and the carbon price.
In other words, the degree of influence on the changes in benefits for renewable energy producers of the three factors is greatest for the quantity of renewable energy purchased in the market, less for the market price for renewable energy, and least for the carbon price. Therefore, improving the quantity of renewable energy consumption is crucial under the electricity safety and stability. In order to promote renewable energy consumption, the renewable energy producers can improve the accuracy of renewable energy generation forecast for the power dispatching department when the TOU is carried out.

The main factor influencing the changes in the benefit for the social environment is the quantity of renewable energy purchased in the market. The sensitivity analysis results are shown in Table 12.

From Table 12, it can be seen that if there is an increase in the quantity of renewable energy purchased in the market, the benefits to the social environment will increase. So the government should promote collaborative development 
among multienergy according to the hydropower, wind power, photovoltaic power generation, and other renewable energy generation characteristics and construct ancillary service markets actively to provide safe and stable on-gird access for renewable energy.

\section{Discussion}

Given the overcapacity in electricity generation, curtailment of renewable energy, and the development of captive coalfired power plants for industrial users, this paper designs a TOU pricing mechanism to promote renewable energy consumption by the substitution of renewable energy for captive coal-fired power plants with a linkage mechanism between the supply side and demand side. As shown in the case study of the Western Inner Mongolia grid in China, the grid company and renewable energy producers' benefits have been improved and users' expenses and $\mathrm{CO}_{2}$ emissions have been reduced.

In the TOU pricing mechanism to promote renewable energy consumption, grid company plays a key role in transmitting between supply and demand to increase power purchase costs savings by purchasing cheap renewable energy for demanders. To ensure the TOU pricing mechanism being carried out successfully, there are some key works that need to be done by the grid company:

(1) Improving the power grid's intelligence and enhancing the control ability for the power grid to ensure renewable energy on grid as much as possible

(2) Improving the forecast accuracy of intermittent power, such as wind power and solar power

(3) Setting a low limit for off-peak price and guiding peak shaving reasonably to prevent inversion between peak load and off-peak load.

Regarding users, the captive coal-fired plants' operation cost per $\mathrm{kWh}$ is related to coal consumption per $\mathrm{kWh}$, coal price, and carbon price. Therefore, the users need to pay attention to coal trading market and carbon emissions trading market to calculate operation cost accurately, which is a determining factor for electricity generated captive coal-fired plants shifting to grid. In addition, when the cheap renewable energy consumption decreased, the power purchase expenses will increase. So users could optimize using electricity behaviors, according to renewable energy generation characteristics to promote renewable energy consumption.

The key factors to renewable energy producers' benefits are the consumption and the price from the renewable energy. So in order to promote the renewable energy consumption, improving the forecast accuracy and generation characteristics of renewable energy is vital.

From the government perspective, the TOU pricing mechanism is conducive to achieving emission reduction commitments and renewable energy consumption targets. Therefore, the government should provide some support for it:
(1) Encouraging multienergy complementary development, such as thermal power, hydropower, wind power, and solar power to ensure the grid operation is stable

(2) Because the coal price, carbon price, and other factors are unstable, the government should focus on the linkage mechanism among coal, electricity, and carbon to adjust the TOU price.

\section{Conclusions and Recommendations}

Combined with the development of the Western Inner Mongolia power grid, this paper studies a TOU pricing mechanism to promote renewable energy consumption, by the substitution of renewable energy for captive coal-fired power plants. The conclusions and recommendations are as follows:

(1) Combined with the load prediction results about the "13th Five-Year Plan" of Western Inner Mongolia grid, if a TOU pricing mechanism is introduced and the peak shaving and the shift to grid are both $2 \%$, the benefits to the grid company will increase by 0.744 billion Yuan, the expenses of power users will reduce by 0.131 billion Yuan, the benefits to renewable energy producers will increase by 0.284 billion Yuan, and $\mathrm{CO}_{2}$ emissions will reduce by up to $3,705.6$ thousand tons.

(2) When TOU pricing is introduced in the Western Inner Mongolia power grid, the biggest factor affecting the benefits for the grid company, the electricity users, the renewable energy producers, and the social environment is the quantity of renewable energy purchased in the market.

(3) With the improvement in the electricity market mechanisms, in order to increase the benefits for the grid company, the electricity users, the renewable energy producers, and the social environment, the government should, when setting the TOU price, take into consideration the costs of the purchase and installation of smart meters, the costs of the operation and maintenance of smart meters, the quantity of renewable energy purchased in the market, the price of renewable energy on the market, and the carbon price.

(4) Based on the lessons learnt from the existing TOU pricing mechanism, smart meters are the vital equipment. So, to ensure the implementation of the TOU pricing mechanism, upgraded smart meters should be promoted to apply the TOU price mechanism based on close cooperation between the government and the grid company. In addition, considering the electricity market development about renewable energy in the TOU price mechanism proposed in this paper, the power generation plan should be released gradually to promote transactions in the power market.

(5) The grid company is responsible for the benefits fluctuation with different peak shaving based on the 
existing TOU pricing mechanism of China, which does not consider the renewable energy. In the TOU price mechanism proposed by this paper, unstable renewable energy has been taken into account, which increases grid company' risk; as a result, it is suggested that a balanced fund accounting for the TOU price mechanism should be established by the local government to ensure the sustainable development of the economic and power industry. In the future, a spot market (a real-time electricity market) should be promoted, and a power balance market should be developed in an orderly and coordinated way with the aim of establishing the full market TOU price mechanism.

\section{Conflicts of Interest}

The authors declare that they have no conflicts of interest.

\section{Acknowledgments}

The paper was supported by the Science Projects Fund of State Grid Corporation of China.

\section{References}

[1] The 21st Century Economic Report, 2017, http://www.chinanengyuan.com/news/news_detail.php?news_id=107884.

[2] Ferro-Alloys.com, 2017, http://www.ferro-alloys.cn/News/ Details/232263.

[3] China News Network, 2017, http://finance.sina.com.cn/roll/ 2017-01-26/doc-ifxzyxxk0675716.shtml.

[4] F. Ren and L. Xia, "Analysis of China's Primary Energy Structure and Emissions Reduction Targets by 2030 Based on Multiobjective Programming," Mathematical Problems in Engineering, vol. 2017, Article ID 1532539, 8 pages, 2017.

[5] Oriental Morning Post, 2015, http://money.163.com/15/1201/09/ B9O8JHAU00253B0H.html.

[6] E. Koçak and A. Şarkgüneşi, "The renewable energy and economic growth nexus in black sea and Balkan Countries," Energy Policy, vol. 100, pp. 51-57, 2017.

[7] I. Cadoret and F. Padovano, "The political drivers of renewable energies policies," Energy Economics, vol. 56, pp. 261-269, 2016.

[8] W. Shen, "Who drives China's renewable energy policies? Understanding the role of industrial corporations," Environmental Development, vol. 21, pp. 87-97, 2017.

[9] Z. Ming, L. Ximei, L. Na, and X. Song, "Overall review of renewable energy tariff policy in China: Evolution, implementation, problems and countermeasures," Renewable and Sustainable Energy Reviews, vol. 25, pp. 260-271, 2013.

[10] V. Bertsch, M. Hall, C. Weinhardt, and W. Fichtner, "Public acceptance and preferences related to renewable energy and grid expansion policy: Empirical insights for Germany," Energy, vol. 114, pp. 465-477, 2016.

[11] S. Strunz, E. Gawel, and P. Lehmann, "The political economy of renewable energy policies in Germany and the EU," Utilities Policy, vol. 42, pp. 33-41, 2016.

[12] Y. He, Y. Pang, J. Zhang, T. Xia, and T. Zhang, "Feed-in tariff mechanisms for large-scale wind power in China," Renewable and Sustainable Energy Reviews, vol. 51, pp. 9-17, 2015.
[13] H. Zhang, Y. Zheng, U. A. Ozturk, and S. Li, "The impact of subsidies on overcapacity: A comparison of wind and solar energy companies in China," Energy, vol. 94, pp. 821-827, 2016.

[14] C. Jeon, J. Lee, and J. Shin, "Optimal subsidy estimation method using system dynamics and the real option model: Photovoltaic technology case," Applied Energy, vol. 142, pp. 33-43, 2015.

[15] M. Andor and A. Voss, "Optimal renewable-energy promotion: Capacity subsidies vs. generation subsidies," Resource and Energy Economics, vol. 45, pp. 144-158, 2016.

[16] J.-Y. Kim, M. H. Lee, and N. Berg, "Peak-load pricing in duopoly," Economic Modelling, vol. 57, pp. 47-54, 2016.

[17] A. A. Alaica and S. B. Dworkin, "Characterizing the effect of an off-peak ground pre-cool control strategy on hybrid ground source heat pump systems," Energy and Buildings, vol. 137, pp. 46-59, 2017.

[18] B. Ye, F. Ge, X. Rong, and L. Li, "The influence of nonlinear pricing policy on residential electricity demand-A case study of Anhui residents," Energy Strategy Reviews, vol. 13-14, pp. 115124, 2016.

[19] X. Z. Zhang and Z. M. Liu, "Residential electricity demand under time-of-use pricing and increasing block pricing: an analysis based on DCC model," Economic Research Journal, vol. 4, pp. 146-158, 2015.

[20] Z. M. Liu, X. Z. Zhang, and D. Yang, "Policy target achievement between pure time-of use tariff and time-of-use block tariff," The Journal of Quantitative \& Technical Economics, vol. 32, pp. 102134, 2015.

[21] H. Hotelling, "The General Welfare in Relation to Problems of Taxation and of Railway and Utility Rates," Econometrica, vol. 6, no. 3, p. 242, 1938.

[22] C. Gong, K. Tang, K. Zhu, and A. Hailu, "An optimal timeof-use pricing for urban gas: A study with a multi-agent evolutionary game-theoretic perspective," Applied Energy, vol. 163, pp. 283-294, 2016.

[23] H. Alayo and R. García, "A static deterministic linear peak-load pricing model for the electricity industry: Application to the Peruvian case," Energy Economics, vol. 50, pp. 202-206, 2015.

[24] A. Nilsson, P. Stoll, and N. Brandt, "Assessing the impact of realtime price visualization on residential electricity consumption, costs, and carbon emissions," Resources, Conservation and Recycling, vol. 124, pp. 152-161, 2017.

[25] Power Knowledge, http://news.solarbe.com/201701/23/108170 .html.

[26] FD.BJX.COM.CN, http://news.bjx.com.cn/html/20140904/ 543677.shtml.

[27] National Energy Administration, http://www.nea.gov.cn/201502/12/c_133989991.htm.

[28] National Energy Administration, http://www.nea.gov.cn/201602/02/c_135066586.htm.

[29] Notice on encouraging fund-raising for electricity and implementing a variety of electricity prices provisional regulations, http://www.chinalawedu.com/falvfagui/fg22016/11801.shtml.

[30] Notice on the implementation method of a variety of electricity price, https://wenku.baidu.com/view/ab7143a2284ac850ad0 242bc.html.

[31] Notice on applying price leverage to regulate the power supply and demand to promote the rational power use related issues, http://www.nea.gov.cn/2011-08/16/c_131052527.htm.

[32] Notice on the implementation of TOU tariff policy on the utilization of electricity by residents, http://www.hebwj.gov.cn/ News.aspx? sole $=20150929160857875$. 
[33] National Energy Administration, http://www.nea.gov.cn/201701/19/c_135996630.htm.

[34] F. T. Zeng, C. L. Chen, and X. B. Tang, "A Simplified Determination Method for Capacity Combination of Wind Power Stations and Pumped Storage Power Stations in West Inner Mongolia Power Grid," Hydropower and New Energy, vol. 138, pp. 75-78, 2015.

[35] P. J. Ge and Y. Li, "An Analysis on Output Characteristics of Photovoltaic Power Stations in Ningxia Area," The New Energy Power Control Technology, pp. 33-36, 2016.

[36] Z. F. Tan, M. B. Wang, J. X. Qi, J. C Hou, and X. Li, "Time-ofuse price optimizing model and fuzzy solving method," Systems Engineering-Theory \& Practice, vol. 9, pp. 145-151, 2008.

[37] F. R. Liao, X. J. Chen, X. N. Liu, and X. T. Kang, "A Review of the Time-of-use Price Decision-making Model," Shandong Electric Power, vol. 41, pp. 17-20, 2014.

[38] FD.BJX.COM.CN, http://news.bjx.com.cn/html/20160411/ 723699-3.shtml.

[39] Y. Bai, Research of Electricity Transactions for Western Inner Mongolia Power Grid with Full Using Wind Power, North China Electric Power University, 2013. 


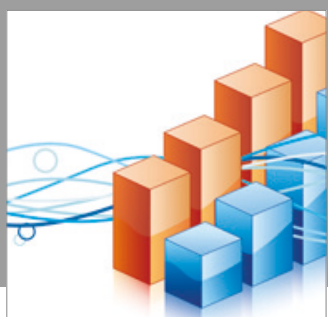

Advances in

Operations Research

vatersals

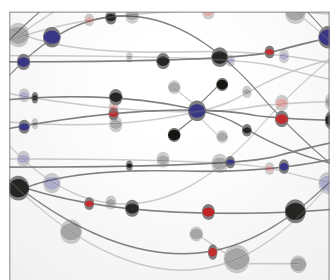

\section{The Scientific} World Journal
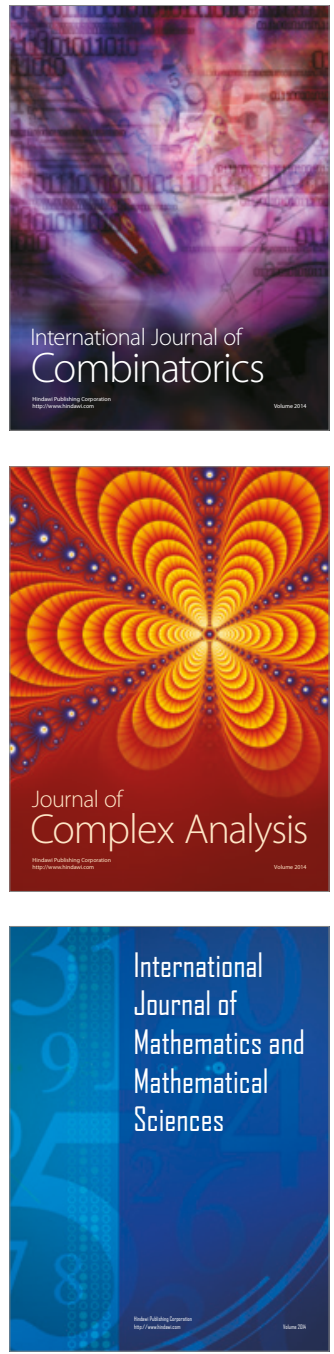
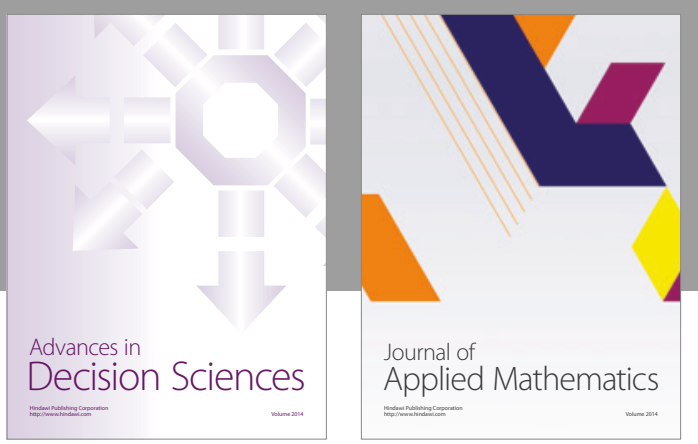

Algebra

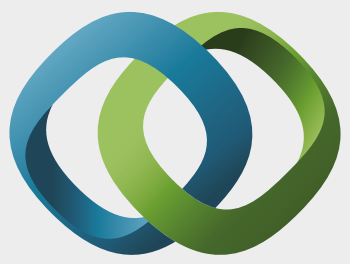

\section{Hindawi}

Submit your manuscripts at

https://www.hindawi.com
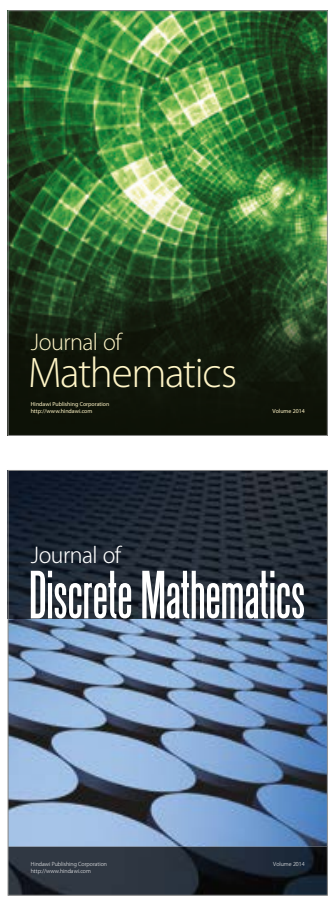

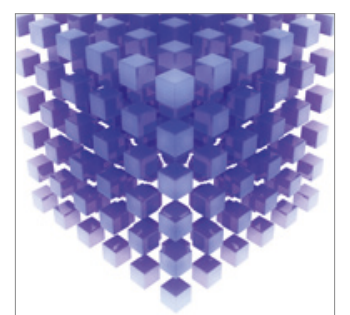

Mathematical Problems in Engineering
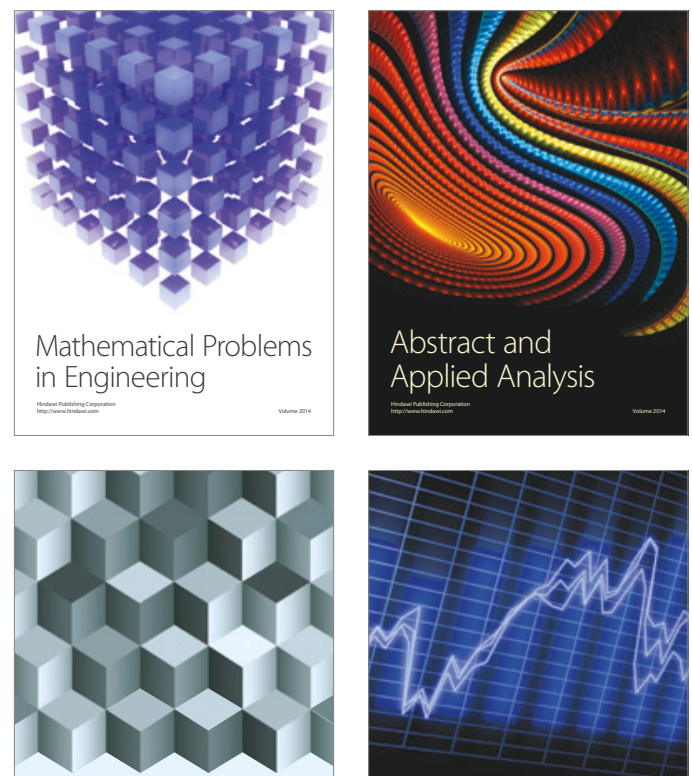

Journal of

Function Spaces

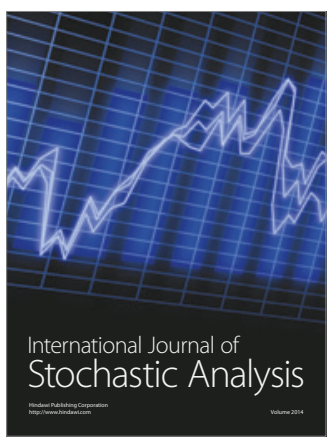

Probability and Statistics
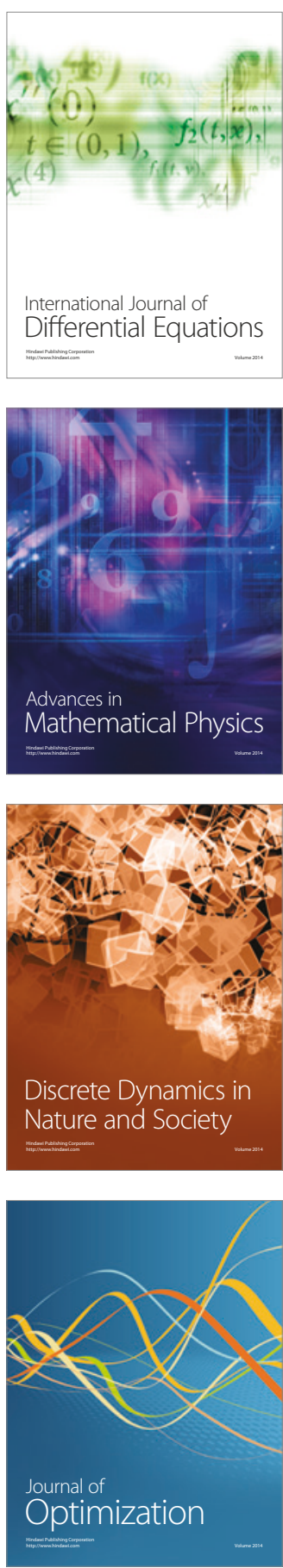